\title{
Regional Hegemony Quests in the Middle East from the Balance of Power System to the Balance of Proxy Wars: Turkey as Balancing Power for the Iran - Saudi Rivalry* \\ Ortadoğu'da Güç Dengesi Sisteminden Vekalet Savaşı Dengesine Bölgesel Hegemonya Arayışları: İran-Suudi Rekabetinde Dengeleyici Güç Olarak Türkiye
}

\author{
Muharrem EKŞi**
}

\begin{abstract}
This study examines the Iran-Saudi rivalry within the context of the changing balance of power in the Middle East. The main research questions were determined to be what the dynamics of the Iran-Saudi rivalry are and what type of role Turkey may play within the rivalry between the two countries. Three essential arguments were developed within this context. The first argument is that the regional balances were broken by the US occupation of Irag in 2003 and by the 'Arab Spring' process resulting in the regional hegemony rivalry between Iran and Saudi Arabia. The second one is that Iran desired to utilize the Arab Spring process as an opportunity to become a regional hegemonic power. On the other hand, the policy of the US to withdraw from and leave the Middle East to its allies Israel and Saudi Arabia caused King Salman bin Abdul-Aziz Al Saud to adopt a regional leadership policy. Within this framework, the study argued that the rivalry to become the new regional hegemon of the Middle East resurged between Iran and Saudi Arabia, the two historic rival powers of the Middle East. The third argument is that the rivalry between the two countries was mainly in the form of a proxy war but resulted in the fact that the balance of power struggle in the region reached to the proxy war balance as no country managed to outcompete the other.
\end{abstract}

Key Words: Saudi Arabia, Iran, Turkey, Proxy War, Balance Of Power, Hegemony Öz

Bu araştırmada Ortadoğu'daki İran-Suudi rekabeti, değişen güç dengeleri bağlamında incelenmiştir. Makalenin temel araştırma sorusu, Iran-Suudi rekabetinin dinamikleri nelerdir ve iki ülke arasındaki rekabette Türkiye'nin rolü ne olabilir olarak belirlenmiştir. Bu bağlamda üç temel argüman geliştirilmiştir: Birincisi, ABD'nin 2003 yıllinda Irak işgali ve 'Arap Baharı' sürecinin bölgesel dengeleri bozduğu ve iki ülke arasında bölgesel hegemon olma rekabetine yol açtığı tezi geliştirilmiştir. İkincisi, İran, Arap Baharı sürecini bölgesel hegemon güç olmak için bir fırsat olarak kullanmak istemiştir. Öte yandan ABD'nin

Makale Geliş Tarihi: 09.03.2017 Kabul Tarihi: 18.09.2017

Asst. Prof., International Relations, Kırklareli University, E-mail: muharremeksi@klu.edu.tr 
bölgeden çekilmesiyle Ortadoğu'yu müttefikleri israil ve Suudi Arabistan'a burakma politikası, Kral Salman’ bölgesel liderlik politikasına yöneltmiştir. Bu çerçevede araştırmada Ortadoğu'nun iki tarihsel rakip gücü olan Iran ve Suudi Arabistan arasında Ortadoğu'nun yeni bölgesel hegemonu olma rekabetinin başladiğı argümanı ileri sürülmüştür. Üçüncüsü, iki ülke arasındaki rekabetin ăgırlkkl olarak vekalet savaşı biçiminde yürütüldügü̈, ancak her iki ülkenin de birbirlerine üstünlük sağlayamaması, bölgede güç dengesi rekabetinin aynı zamanda vekalet savaşı dengesine dönüştüğ̈̈ argümanı ileri sürülmüştür.

Anahtar Kelimeler: Suudi Arabistan, Iran, Türkiye, Vekalet Savaşı, Güç dengesi, Hegemonya

\section{Introduction}

After the US occupation of Iraq in 2003, the balance of power in the Middle East started to change. Likewise, Iraq was no more one of the balance of power in the Middle East policy. However, the development that really turned the balance of powers upside down in the Middle East was the Arab Spring process that started in 2010. In this process, Libya, Egypt and Syria were no more the balance of power of the Middle East policy, creating a big gap of power vacuum in the region. Moreover, the strategy of the US to shift its power from the Middle East to the Asia-Pacific resulted in a new rivalry of hegemonic power in the Middle East. Russia started to settle in the Middle East over the Syria crisis and adopted the strategy to replace the US in the region. On the other hand, the US administration implemented a strategy of maintaining its influence in the Middle East through its allies. Accordingly, the US shifted its power to China, a superpower candidate, and opted to leave the Middle East to its allies: Israel and Saudi Arabia!

King Salman, who came to the throne in Saudi Arabia in January 2015, followed a hawkish policy and started the Yemen operation in March, which was a clear display of its ambition to become a regional hegemony in the Middle East ${ }^{2}$. This started the rivalry of becoming the new the regional hegemon of the Middle East between Iran and Saudi Arabia, the two historic rival powers of the region. Yemen and Syria turned to be the areas of proxy wars between the two powers. On the other hand, the nuclear reconciliation between Iran and the $5+1$ countries in July 2015 and the Iran-US rapprochement started to escalate the rivalry between the Saudi Arabia and Iran. However, the Yemen operation was a clear demonstration of the limits of the Saudi Arabia to become a regional hegemon ${ }^{3}$. The policy of Saudi Arabia to turn its oil and capital wealth

1 Fahad Nazer, “ABD’yle Suudi Arabistan'ın “Özel ilişkisi” sürecek mi?”, Al-Monitor, Gulf Pulse, Nisan 8, 2016, Erişim tarihi: 04.12.2016, http://www.al-monitor.com/pulse/tr/originals/2016/04/us-saudi-relations.html\#

2 Madawi Al-Rasheed, "Saudi Arabia and the quest for regional hegemony", Hurstpublishers, 19 July 2016, Erişim tarihi: 18.12.2016, http://www.hurstpublishers.com/saudi-arabia-quest-regional-hegemony/

3 Mohammed Nuruzzaman, "Saudi Airstrikes on Yemen: Limits to Military Adventu- 
to a regional hegemony was not sufficient, as its economic power alone cannot make it a regional hegemony due to its inadequate military power ${ }^{4}$. Therefore, Saudi Arabia needs to make ally with a country with more military capacity to become a hegemonic power.

At this point emerges the option of alliance between Turkey and Saudi Arabia to become a joint regional hegemons. It was clear that the two countries could not become the hegemonic power of the region despite the support of the US. However, the eventual alliance between the two countries was overshadowed by the fact that Turkey was a rival of Saudi Arabia just like Iran. Likewise, Turkey leaded by AK Party followed a policy of becoming a regional power in the Middle East between 2003 and 2013; however, the Arab Spring disrupted this policy. Therefore, it is anticipated that the future of the US-Iran rapprochement at the regional level and the progress of the relations between Saudi Arabia and Turkey will determine how the balance of power in the Middle East will be shaped. On the global level, it could be argued that the US-Russia relations and their Middle Eastern policies will determine both the balance of power and the fate of the region.

\section{From the Balance of Power to the Proxy War}

The regional balance of power system in the Middle East based upon the actors like Iraq, Iran, Israel, Egypt and Turkey started to change in 2000s. Firstly, Iraq was no longer a regional power with the US occupation in 2003. The main change started with the Arab Spring process in 2010; and Turkey, Egypt and Syria, that were the main regional actors of the Middle East, ceased to be the power centres. Even further, they were no longer the actors of the Middle East as they were replaced by Iran and Saudi Arabia. The regional hegemonic rivalry resurged between Iran and Saudi Arabia in the Middle East. This rivalry takes place in the form of proxy wars.

The concepts of proxy war, balance of power and hegemony will be used as analytical instruments to understand and analyze the developments in the Middle East. Likewise, the dynamics and the theoretical framework of the rivalry between Iran and Saudi Arabia consist of the concepts like balance of power, security dilemma and proxy war.

\section{Balance of Power}

Historically, the Middle East is interpreted with the balance of power system. That is, the region is conceptualized within the balance of power theory. The region is constructed with the concepts like realpolitik, geopolitics, geostrategic,

rism", E-International Relations, May 20, 2015, Erişim tarihi: 26.12.2016, http://www.e-ir. info/2015/05/20/saudi-airstrikes-on-yemen-limits-to-military-adventurism/

4 F. Gregory Gause III, Saudi Arabia in the New Middle East, Council on Foreign Relations, Council Special Report No.63, December 2011, New York, p. viii.

Akademik Bakış 135 Cilt 11 
security, war and terror. Historically again, the region is understood since the World War I as the game area, conflicts of interest, hegemonic struggles of the great powers and external powers. The competitive relations between Iran and Saudi Arabia reflect the classical balance of power theory; therefore, the balance of power needs to be explained theoretically and conceptually within the disciplines of International Relations. First of all, the balance of power in the narrow and simple sense can be described as a condition and structure with no hegemonic power among states and where states have relatively equal or similar powers ${ }^{5}$. In fact, balance of power is a concept of Realism among the mainstream theories of International Relations as well as a separate theory itself 6 . If the two are combined, balance of power is a theoretical concept. Realist paradigm basically considers the international politics to be power relations and even it reduces the whole politics to the power politics. In this sense, the power-seeking is a priority for states in the classical realism.

On the other hand, Neorealism presupposes that states give priority to maintain and the balance of power. In another words, neorealism is based upon the balance of power in the struggle between the states and argues that this provides stability of the international system. On the other hand, defensive realism suggests that a balancing country will emerge once a state gains too much power ${ }^{7}$. In this sense, it could claim that first Turkey and then Saudi Arabia emerged as balancing countries against the power increase of Iran in a process when Syria, Egypt and Iraq were no more actors in the Middle Eastern balance of power following the US occupation of Iraq in 2003 and predominantly Arab Spring in 2011. On the other hand, one can suggest that the balancing power function of Turkey emerged in the balance of power rivalry between Iran and Saudi Arabia. John Mearsheimer, an offensive realist, argues that the system by nature will push countries to gain more power and to become hegemons ${ }^{8}$. In this context, the circumstances that took place after the withdrawal of the regional powers of the Middle East, i.e. Iraq, Egypt, Syria and Turkey, pushed Iran and then Saudi Arabia to pursue a regional hegemony.

Based on this fact, the balance of power also offers a structural approach. Accordingly, bipolar or multipolar balance of power structures emerge in the international and regional system. Within the framework of the Middle East politics, it is probable to notice a multipolar structure in the region until 2003

5 T.V. Paul, James J. Wirtz and Michel Fortmann (ed.), Balance of Power: Theory and Practice in the 21st Century, Stanford University, Stanford, California, 2004, p.2.

6 a.g.e., p.9

7 a.g.e., p.32.

8 John J. Mearsheimer, The Tragedy of Great Power Politics, W.W. Norton E Company, New York, London, 2001, p.157.

9 Michael Sheehan, The Balance of Power: History \& Theory, Routledge, London and New York, 1996, p. 188. 
including Iraq, Iran, Egypt, Israel and Turkey. On the other hand, balance of power could be established bilaterally and multilaterally. As it can be discussed later, when the balance of power could not be established between Iran and Saudi Arabia; Gulf countries and Turkey stood by Saudi Arabia that would create a multilateral balance of power against Iran (Shia crescent: Iraq, Lebanon, Syria). One of the strategies of balance of power is to achieve it by applying the alliance system ${ }^{10}$. However, the rivalry creates security dilemma between the two countries. The security dilemma was first developed as a concept in 1950 by John H. Herz ${ }^{11}$. According to Herz, the security dilemma serves as a mechanism that shapes the relations between actors in the event of anarchy ${ }^{12}$. In simple words, when a country adopts a policy of improving its security by armament after perceiving a threat from another country, the other country also adopts the policy of improving security that results in the security dilemma. The security dilemma becomes another dynamic other than the balance of power that shapes the relations between Iran and Saudi Arabia. As it will be discussed later, the security dilemma is in fact the source of the rivalry between two countries. In other words, the security dilemma nourishes the rivalry between two countries.

On the other hand, the balance of power is fundamentally related to the international distribution of power. The balance of power in the international distribution of power can emerge as a simple or complex balance of power. In the simple balance of power, there is a kind of equality between the powers of two countries while the complex balance of power refers to the condition of more than two rivalries in the complexity of balance of power. If it is adapted to the Middle East, there is a simple balance of power between Iran and Saudi Arabia in the narrow sense, while the complex balance of power may include Iran, Saudi Arabia, Turkey and Israel as regional power in the region. In fact, Barry Buzan and Ole Weaver, ranks states hierarchically as superpower, great power, and regional power in determining the power category in the international system ${ }^{13}$. Iran and Saudi Arabia are listed as regional powers in the geopolitics of Middle East after 2011. Regional power can be defined as a power that is effective in its own region, but has limited global effect and no involvement in most of the global developments. On the other hand, regional powers can have an impact on the policies of great powers. At the same time, regional power could be defined as a state that has a hegemonic function

Akademik Bakış 137 Cilt 11 Sayı 21 Kış 2017

10 Hans J. Morgenthau, Politics Among Nations: The Struggle for Power and Peace, A. A. Knopf, 1948, p. 187.

11 In addition to Herz, Robert Jervis and Herbert Butterfield are the first to develop the concept. Shiping Tang, "The Security Dilemma: A Conceptual Analysis", Security Studies, 18:3, 587-623, 2009, p. 587.

12 John Herz, Political Realism and Political Idealism: A Study in Theories and Realities, Chicago: University of Chicago Press, 1951, p. 14.

13 Barry Buzan and Ole Waever, Regions and Powers: The Structure of International Security, Cambridge University Press, Cambridge, New York, 2003, p.34-35. 
and potential in its region ${ }^{14}$. In this sense, Iran and Saudi Arabia started the struggle of balance of power after 2011, while they also went into a regional hegemonic rivalry. The rivalry between the two countries manifests itself in the form of a proxy war.

\section{Balance of Proxy War}

Karl Deutsch simply defines proxy war as the international conflict between two countries in a third country ${ }^{15}$. In more details, Andrew Mumford defines proxy war to be a way of conflict where State A uses proxies in indirect engagements through secret destructive operations against the State $\mathrm{B}^{16}$. Based on these definitions, the proxy war is understood to be a way of conflict that takes place indirectly and secretly in another country through the use of proxies where states do not fight directly. Historically, proxy war emerged as the product of the Cold War period as a way of struggle between the US and the Soviets. In that period, the balance of terror emerged by the mutual destructiveness of nuclear powers between the two superpowers prevented direct conflict and caused proxy wars.

On the other hand, the concept of proxy war is getting popular as a way of conflict within the struggle between countries in the $21^{\text {st }}$ century. Today, proxy wars take place as an expression of conflicts of interests between countries. It mainly emerges in countries with escalating civil war after Cold War. Particularly the change of balance of power and power distributions in the international system particularly after the Cold War is the principal systemic dynamic that reveals the fact of proxy war again. Relative weakening trend of the US, the rise of China, a superpower candidate, and the conflicting interests of Russia and the US make the proxy war popular. The main hypothesis of Robert Gilpin in his War and Change book which asserts that the change of international system will take place through great wars ${ }^{17}$ is paraphrased towards the argument that this change will be over the proxy wars. In this sense, it is understood that the proxy wars play a role that may change the international system.

The new dynamics that create the fact of proxy war:

- Relative weakening of the US

- The Rise of China

- The US-China rivalry

- The Rise of Russia under the leadership of Putin and its quest of great

14 a.g.e., p.37

15 Andrew Mumford, Proxy Warfare, Polity Press, Cambridge, 2013, p.13.

16 Andrew Mumford, "Proxy Warfare and the Future of Conflict", The RUSI Journal, Vol. 158, Issue 2, 2013, pp.40-46, p. 41.

17 Robert Gilpin, War and Change in World Politics, Cambridge University Press, Cambridge, 1984. 
power status in the international system, its conflict based policy with the US and the conflicting interests

- Conflicting interests between Russia and the US in Ukraine and Syria; and the transformation of these two countries into the fields of proxy wars

- The increase of geopolitical rivalry in the $21^{\text {st }}$ century global politics

- $\quad$ The increase of conflicting interests in the $21^{\text {st }}$ century global politics

- New style policies particularly in the Middle East

- The Redesigning process of the Middle Eastern geopolitical system after the 'Arab Spring'

- The increase of the failed state phenomenon

- The increase of effects and roles of non-state actors in global politics

- The emergence of terrorist organizations as challengers to the state actor

- $\quad$ The cooperation of states with terrorist organizations and their using it in proxy wars

- $\quad$ The spread of asymmetric wars

- The avoidance of states from direct battles due to developments in the military technology

- The evaluation of the proxy war method by the states to be a strategic choice as a way of conflict and as an instrument to realize their foreign policy objectives.

- The fact the proxy war contains less risks and costs compared to direct battles

The above-mentioned facts intensify the proxy wars in the 21 st century especially in Africa and the Middle East. The proxy wars are in the trend of escalation between the US and China in Africa, between Russia-Iran and the US in the Middle East, between the EU and Russia in Europe (Kosovo, Ukraine), and between Russia and the US-NATO in Caucasus ${ }^{18}$. The proxy wars particularly in the Middle East started in 2003 with the occupation of Iraq in 2003 and spread through the 2011 Arab Spring process ${ }^{19}$. In the process after 2003, Iraq lost importance as even an actor let alone becoming a no more regional power. Iraq became a failed state after occupation and turned to be the field of proxy war between the US and $\operatorname{Iran}^{20}$. During the Arab Spring process, Libya became a country of civil war and a failed state and it was no more the power of the Middle East and North Africa. Egypt became a failed state after

18 Mehmet Seyfettin Erol, Çiğdem Tunç, “11 Eylül Sonrası ABD’nin Küresel Güç Mücadelesinde Orta Asya”, Avrasya Dosyası, Cilt: 9, Sayı: 3, Sonbahar 2003, pp.5-28, p.12.

19 Aaron Reese, Sectarian and Regional Conflict in the Middle East, The Institute for the Study of War, July 2013, p.9

20 Thomas Joscelyn, Iran's Proxy War Against America, The Claremont Institute, 2007.

Akademik Bakış 139 
the riots during the Arab Spring process and was no more a regional power particularly after Egypt's first elected President Mohammed Morsi whom coup was made. Turkey managed to shine as a rising soft power in the leadership of Middle East between 2003 and 2010 relatively, but had to withdraw from its regional leadership policy by going into the swamp of the Syria crisis in 2011.

Even more, after the start of a long civil war in Syria in 2011, the country turned to be an area of proxy war between great powers and regional powers $^{21}$. In this sense, the balance of power in the Middle East changed all the way. After an increase of influence in Iraq, Iran achieved the position of regional power and regional leader in the geopolitics of the Middle East ${ }^{22}$. This naturally became a factor that deeply affected the balance of power in the Middle East. The increasing influence of Iran in the region, especially the Shia crescent turned to be a source of threat for the Gulf countries particularly for Saudi Arabia ${ }^{23}$. The changing balances in the Middle East increased the rivalry between Iran and Saudi Arabia and this rivalry took the shape of proxy war between the two countries. The fact that the balance of power in the Middle East turned upside down with the Arab Spring process increased the quest for a new regional power and particularly the rivalry between Iran and Saudi Arabia for the leadership in the Middle East. The fact that the rivalry between the two countries turned to be a proxy war resulted in the emergence of proxy war balance instead of balance of power system in the Middle East. In other words, the regional balance of power system in the Middle East was replaced by the balance of proxy war. As it will be discussed in detail later in this article, the rivalry between Iran and Saudi Arabia continued in the form of proxy wars while the failure of both countries to outcompete the other was conceptualized as the balance of proxy war ${ }^{24}$.

\section{Iran's foreign policy}

After the Iran's Islamic Revolution in 1979, it was not only Iran's foreign policy changing, but also a new State of Iran emerged. This changed the balance of power in the Middle East and leaded to the Iran-Iraq war (1980-1988). This war turned to be Iraq's war of prevention of the regime exportation policy of Iran after the revolution, Iraq being the most powerful even the leader state of the

21 The Syrian Conflict: A systems Conflict Analysis, ARK Group, February 2016, p.14.

22 Tarek Osman, "Iran's Play for Middle Eastern Leadership", Foreign Affairs, January 20, 2017, Erişim tarihi: 28.01.2017,https://www.foreignaffairs.com/articles/middle-east/2017-01-20/ iran-s-play-middle-eastern-leadership

23 Emmanuel Karagiannis, "The rise of Iran as a regional power: Shia empowerment and its limits", NATO Review Magazine, 2016, Erişim tarihi: 05.11.2016, http://www.nato.int/docu/Review/2016/Also-in-2016/iran-regional-power-tehran-islamic/EN/index.htm

24 J. Dana Stuster, “The Limits of Iran's Regional Ambitions", National Security Network, Policy Brief, July 9, 2015, p. 1-9, p.6, Erişim tarihi: 14.08.2016,

http://nsnetwork.org/cms/assets/uploads/2015/07/StusterLimitsIransRegionalAmbitions.pdf 
Middle East at that time. Apart from that, the Iran-Iraq war was a war of regional hegemony. After the revolution, Iran built its foreign policy on the leadership of Muslims, particularly the Middle East. The regime defined itself as the defender and protector of all Muslim societies. Iran first began to build the Shia geopolitics over the Shia population by religious discourse ${ }^{25}$. It increased its influence on Shiite people and produced a sectarian-ideology-based foreign policy that aspires to make those people the strategic instruments of the propaganda policy of Iran.

Although the Shia population in the world is around $10 \%$ of the Muslim population, the condition in the Middle East provides a critical advantage to Iran to become a regional leader. The Shia population in Iraq constitutes the 60-65\% of the total population, 70\% in Bahrain, 35\% in Yemen (Zeydi-Zaydis), 35\% in Lebanon, 30\% in Kuwait, 20\% in Qatar, 16\% in United Arab Emirates (UAE), 10-12\% in Syria (Nusayris-Alawis) and 15 in Saudi Arabia ${ }^{26}$. Among them, the Shia population in Iraq, Lebanon, Syria and Gulf Countries are within the influence area of Iran. The Shia geopolitics that Iran intends to create is called as the Shia Crescent in the Middle East. The Shia Crescent concept was first coined by King Abdullah of Jordan. The King made a statement in 2004 and said that the Sunni Arab countries were encircled by the Shia Crescent extending from Iran to Lebanon covering Iraq and Syria ${ }^{27}$. Similarly, Hosni Mubarak, the former president of Egypt stated on a TV channel in 2006 that the Shia population living in the Middle East felt commitment towards Iran more than the countries they lived in ${ }^{28}$. Finally, longstanding Saudi foreign minister Prince Saud bin Faisal made similar corresponding statements with these two leaders ${ }^{29}$.

As it can be seen, the policy of Iran to create a Shia Crescent was defined by the neighbouring Sunni countries as a source of threat and a security problem $^{30}$. The main reason of Iran to develop a foreign policy generally over the Shia people is based upon the idea that it cannot win the support of the Sunni states in its strategy of regional leadership. On the other hand, religion

25 Heshmatollah Falahat Pisheh, "Shi'ite geopolitics and Iran's foreign policy", International Journal of Economy, Management and Social Sciences, Vol(3), No (5), May, 2014. pp. 278-281, p. 278.

26 Mari Luomi, Sectarian Identities or Geopolitics? The Regional Shia-Sunni Divide in the Middle East, The Finnish Institute of International Affairs, Helsinki, 2008, p.3.

27 Ian Black, "Fear of a Shia full moon", The Guardian, January 26, 2007, Erişim tarihi: 25.09.2016; https://www.theguardian.com/world/2007/jan/26/worlddispatch.ianblack

28 Fadi A. Haddadin, "The 'Shia Crescent' and Middle East Geopolitics”, Foreign Policy Association, January 31, 2017, Erişim tarihi: 02.02.2017, http://foreignpolicyblogs.com/2017/01/31/ shia-crescent-middle-east-geopolitics/

29 Juan Cole, Kenneth Katzman, Karim Sadjadpour, Ray Takeyh, “A Shia Crescent: What Fallout for the United States?”, Middle East Policy, Vol. 12, Issue 4, 2005, pp. 1-27, p.3.

30 Kayhan Barzegar, "Iran and the Shiite Crescent: Myths and Realities, Journal of World Affairs, Fall/Winter 2008, Vol. XV, Issue 1, pp. 87-99, p.87. 
was instrumentalized as rhetoric in the foreign policy of Iran. This refers to the fact that Iran underlines the Shia identity in the regions where Shia people live and the Muslim identity anywhere. In this sense, Iran intrinsically follows a pragmatic foreign policy with the ambition of becoming a regional leader ${ }^{31}$. Therefore, Iran chose the public diplomacy that takes place from the state towards the people instead of the classical diplomacy from state to state. With the public diplomacy policy rested on winning the support of people, Iran formulated its policy about managing the people ${ }^{32}$. Thus, Iran developed its policy of winning the support of the Shiite people first and then becoming the protector of Muslims over a religious discourse by securing the leadership in the issue of Palestine ${ }^{33}$. Likewise, the Iranian President Hatemi launched the Initiative for Dialogue between Civilizations at the UN in 2001 and tried to realize its policy of leadership in the Muslim world at a global level.

The increasing influence of Iran after the US occupation of Iraq in 2003 started to get a new momentum with the 'Arab Spring' process in 2011. Iran regarded the Arab Spring as a movement of Islamic awakening and desired to play the role of leadership of this movement. Iran took the Arab Spring as an opportunity to overthrow the Sunni governments and tried to make the Shiite people in Sunni countries rebel. This policy of Iran was perceived as a threat for the survival by the Gulf countries, particularly Saudi Arabia. Likewise, Saudi Arabia responded militarily to the campaign of Iran in Bahrain. After that, Saudi Arabia instead of Iraq became a counter-hegemonic power against Iran in the Middle East. Thus, the historical rivalry between Iran and Saudi Arabia escalated after the Arab Spring. Proxy wars took place between these countries in the Gulf Countries, Iraq, Yemen and Syria.

\section{Foreign Policy of Saudi Arabia}

Just like Iran, Saudi Arabia also regards itself as the natural leader of the Muslim world based upon the fact that it consists of two holy cities of Islam, i.e. Mecca and Medina. Within this framework, Saudi foreign policy was built on the objective of leadership of the Muslim world particularly including the security of the regime ${ }^{34}$. The reason of having the regime security as a main

31 R. K. Ramazani, Independence without Freedom: Iran's Foreign Policy, University of Virginia Press, Virginia, 2013, p.184.

32 Frederic Wehrey, Theodore W. Karasik et. al, Saudi-Iranian Relations Since the Fall of Saddam Rivalry, Cooperation, and Implications for U.S. Policy, Rand Corporation, Santa Monica, USA, 2009, p. 21 .

33 Latife Reda, "Origins of the Islamic Republic's Strategic Approaches to Power and Regional Politics: The Palestinian-Israeli Conflict in Khomeini's Discourse", Middle East Critique, 25:2, 181-203, 2016, p.182; Burhanettin Duran and Nuh Yllmaz, "Islam, Models and the Middle East: The New Balance of Power following the Arab Spring", Perceptions, Winter 2013, Volume XVIII, Number 4, pp. 139-170, p.143.

34 Ertan Efegil, “Suudi Arabistan'ın Dış Politikasını Şekillendiren Faktörler”, Ortadoğu Analiz, Cilt 5, Sayı 53, Mayıs 2013, pp. 104-113, p. 106. 
foreign policy principle is that the country has a relatively weak internal structure and that it was historically built as an artificial state. In fact, Saudi Arabia was built artificially within the framework of the strategic interests of British Empire and France during the partition process of the Middle Eastern lands of the Ottoman Empire after the World War I by these two colonist empires. On the other hand, regime security was regarded as a main foreign policy instrument as the Shia population of $15 \%$ in the country was exploited by Iran $^{35}$. In addition, Iran perceived the Wahhabi Saudi authority as a threat to itself, which was another reason of giving priority to the regime security ${ }^{36}$. As a matter of fact, the regimes of both countries mutually regard themselves as threats.

Therefore, the Saudi authority follows a status quo policy to maintain the existing balance of power both internally and externally along the axis of regime security ${ }^{37}$. In this sense, Saudi foreign policy is based on maintaining the existing balances. Likewise, Saudi Arabia perceived the change of balances in the Middle East during the Arab Spring process as threats to itself and to the regional status quo that it tried to protect ${ }^{38}$. It did not hesitate to intervene immediately to the risk of collapse of the regimes of the Gulf countries during the Arab Spring which it considered as its zone of influence and even as its own backyard. When Arab Spring spread to Bahrain, it immediately sent troops to this country. Again, the Saudi authority found the overthrow of the Mubarak regime in Egypt to be against its interests and provided huge financial support to the Abdel Fattah al-Sisi government let alone supporting the overthrow of the post-Mubarak Morsi government by a coup. In addition, it did not stay silent to the increase of Iran's influence in Yemen and went into a proxy war with Iran. Therefore, these moves of Saudi Arabia are because of its foreign policy to maintain the balance of power system in the Middle East. Thus, Saudi foreign policy to maintain the status quo and the existing balance of power system after the Arab Spring caused it to enter into a regional rivalry with Iran. The balance of power system in the rivalry between Iran and Saudi Arabia was replaced by the balance of proxy war as no country outcompeted the other in the proxy wars as yet.

In the final analysis, the Saudi foreign policy was directed to a new aggressive foreign policy including the military power instruments during the Arab Spring and the time of the new King Salman, although the country

35 Joost Hiltermann, "A New Sectarian Threat in the Middle East", International Review of the Red Cross, Vol. 89, No. 868, December 2007, pp. 795-808, p. 795.

36 Kenneth Katzman, Iran's Foreign and Defense Policies, Congressional Research Service, 2017, p.1.

37 Benedetta Berti and Yoel Guzansky, "Saudi Arabia's Foreign Policy on Iran and the Proxy War in Syria: Toward a New Chapter?", Israel Journal of Foreign Affairs, VIII:3, 2014, pp. 25-34, p. 25.

38 Madawi Al-Rasheed, " Sectarianism as Counter-Revolution: Saudi Responses to the Arab Spring", Stud Ethn Nation, 11: 513-526, p. 513. 
was an oil-based financial power country and traditionally relied upon petrodollar diplomacy ${ }^{39}$. In addition, the status quo foreign policy evolved to a revisionist foreign policy to become a regional leader with the administration of King Salman ${ }^{40}$. Thus, Saudi Arabia exceeded its effect enhancement policy by holding financial power, which it followed until the Arab Spring, and it started a quest for the regional hegemony by adding its military power. The fact that Saudi Arabia entered into a quest for the regional hegemony through a shift from the status quo policy to revisionist policy in the Middle East is based on three essential dynamics. First of all, the regional balance of power system as a regional dynamic was removed with the Arab Spring. Thus, the fact that the regional powers including Iraq, Egypt and Turkey had to abandon the leadership quest of survival policy opened a space to Saudi Arabia, which eliminated its rivals. The second, country based dynamic is the fact that the Saudi authority regarded the regional hegemony quest of Iran as a threat to itself and does not want to leave the leadership of the Middle East to Iran. The third, global-systemic dynamic is the fact that the US left the leadership in the region to its allies Israel and Saudi Arabia within the framework of its strategy to shift its power to Asia-Pacific. These factors resulted in the regional hegemonic rivalry between Saudi Arabia and Iran.

\section{Iran-Saudi Arabia Rivalry}

The rivalry between Iran and Saudi Arabia dates back to the pre-Arab Spring period. Predominantly, the historic foundation of the rivalry between the two countries is rested upon sectarian differences. The historical ground of the rivalry between the two countries is the 1979 Iran Islamic Revolution ${ }^{41}$. In this context, there was an ideological rivalry between the two countries at the beginning. A rivalry inherently started between Wahhabi Sunnism and Shia. The rivalry between the Wahhabi Saudi Arabia and the Shia Iran is based on the leadership of the Muslim world beyond the regional leadership. Iran acts on its organic ties with the Shiite people and follows a policy of increasing its influence over the Shiite people under Sunni administrations by establishing a patronage relationship and this shifts the relations with Saudi Arabia from rivalry to conflict ${ }^{42}$. The fact that the actors within the Shia crescent/triangle act in line with Iran proves to be a threat for all Sunni states particularly Saudi Arabia. Yet Iran becomes an effective actor in the politics of the other countries

39 Toby Matthiesen, " The domestic sources of Saudi foreign policy: Islamists and the state in the wake of the Arab Uprisings", Brookings Working Paper, August 2015, p.7.

40 Sandhya Jain, "Saudi Arabia: King Salman Faces the 21st Century", Strategic Analysis, Vol. 39, Issue 3, 2015, pp. 280-286, p.280.

41 Hani Ahmed Al-Shboul and Mohammad Salim Al-Rawashdeh, "Iran's Foreign Policy and the Balance of Power in the Region", Journal of Politics and Law, Vol. 6, No. 4; 2013, pp. 200-209, p. 200.

42 Jill Ricotta, " The Arab Shi'a Nexus: Understanding Iran's Influence in the Arab World", The Washington Quarterly, 39:2 pp. 139-154, p.142. 
due to the relations it has with the Shiite people in the Middle East. Thus, Iran has the chance to influence and even direct the politics of the countries with Shiite population in the Middle East. Particularly, Iran, Lebanon and Iraq shape their politics this way. This makes Iran a regional power by patronizing the countries of the region and acquires the leadership position. Therefore, the Iran-Saudi Arabia rivalry is historically based upon the Sunni-Shia conflict.

On the other hand, the Iran-Saudi rivalry takes place beyond the sectarian differences. The other dynamics of the rivalry between the two countries consists of the geopolitical axis. Geopolitically both countries tended to take the opportunity of the fact that the geopolitics of the countries in the Middle East was in the process of change again with the Arab Spring in order to realize their historic assertions of domination in the Gulf43. With the Arab Spring process, the change of the geopolitics of the Middle East not only revealed the covert rivalry between the two countries but also moved the rivalry into a conflict atmosphere in the form of proxy war. The conflict areas of the Iran-Saudi rivalry where proxy war takes place are Bahrain, Yemen and Syria. In addition, the rivalry over Egypt looks like to end for now in favour of Saudi Arabia. Because Egypt was in close relationships with Saudi Arabia during the Mubarak administration while the collapse of the Mubarak regime with the Arab Spring caused a loss of position for Saudi Arabia ${ }^{44}$.

However, the fact that Morsi from the Muslim Brothers supported by Iran came to power and the subsequent risk of rapprochement with Iran were considered to be a new source of threat for Saudi Arabia and a development that destroys the balance of power. Therefore, Saudi Arabia did not only supported the el-Sisi coup and but also got Egypt aligned with itself by providing huge amount of economic assistance ${ }^{45}$. The rivalry on Egypt was gained by Saudi Arabia as yet. On the other hand, it should be remembered that Iran previously won in the war with Iraq. Iran won Iraq with the fact that the Shia governments came to power after the collapse of the Sunni Ba'ath regime in the post-2003 process. This was the reason why Saudi Arabia provided a financial assistance of 8 billion USD and committed to meet the 5-year petrol demand in order not to lose Egypt after Iraq ${ }^{46}$.

On the other hand, Iran took advantage of the riots in the Middle East that started with the Arab Spring and wanted to break the protection of Saudi

43 Ariel Jahner, "Saudi Arabia and Iran: The Struggle for Power and Influence in the Gulf", International Affairs Review, Vol. XX, No.3, Spring 2012, pp. 37-50, p.38.

44 Azzurra Meringolo, "From Morsi to Al-Sisi: Foreign Policy at the Service of Domestic Policy", Insight Egypt, N.8, March 2015, pp.1-12, p.3.

45 Karen E. Young, "The Limits of Gulf Arab Aid: Energy Markets and Foreign Policy", European Centre for Energy and Resource Security, Vol. 1 07, Summer 2015, pp. 43-53, p.46.

46 "Saudi Arabia announces oil assistance, investments for Egypt", Ahram Online, Wednesday 16 December 2015, Erişim tarihi: 22.12.2016, http://english.ahram.org.eg/NewsContent/1/64/173627/Egypt/Politics-/Saudi-Arabia-announces-oil-assistance,-investments.aspx

Akademik Bakış 145 Cilt 11 Sayı 21 KıŞ 2017 
Arabia over the Gulf countries while attempting to expand its zone of influence by urging the Shiite people, that make around $70 \%$ of the population of Bahrain, to upraise against the Sunni authority. However, Saudi Arabia acted immediately and sent troops to suppress the Shia riot in Bahrain together with the UAE, its ally in the Gulf. Thus, the policy of Iran to destroy the domination of Saudi Arabia in the Gulf region failed for now. However, Iran continues to apply pressure on the oil-rich Gulf countries including Kuwait and Bahrain over the Shia population. Particularly the disputed islands in the Gulf region continue to be a source of conflict and element of threat between Iran and the Gulf countries. Conversely, the Gulf countries advanced their military alliance relationship with Saudi Arabia and the US, against Iran. In addition to the threat from Arab Spring, it helps consolidate Saudi influence and helps create Saudi-led coalition as central power ${ }^{47}$. Therefore, Gulf region continues to be the most critical sphere of the power struggle between Iran and Saudi Arabia. The control of the Gulf region is the most strategic area of rivalry as it also refers to the control of oil.

Yemen is another field of rivalry between the two countries. The Shia Zaidis or Houthis in Yemen, which are around 35\% of the population, constitute the means of Iran in the politics of Yemen. The start of conflict by the Shia Houthis against the Sunni Hadi government turned the country into an area of proxy war between Iran and Saudi Arabia. Saudi Arabia did not look at the overthrow of the Hadi administration by the Houthis with the support of Iran and launched an air campaign in 2009 against Yemen first by declaring the Houthis as terrorist organization. Then, the allies of Saudi Arabia in Yemen, i.e. Kuwait, the UAE, Egypt, Morocco, Jordan, Qatar and Bahrain started to provide support to the Yemen operation ${ }^{48}$. Particularly, Egypt supported the Yemen operation of Saudi Arabia by 25 fighter jets, the UAE by 30, Kuwait 15 and Qatar 10 warplanes ${ }^{49}$. Thus, Saudi Arabia managed to create a multinational power in the Yemen operation. Even Turkey made a statement of support to the military operation leaded by Saudi Arabia. This was the start of regional polarization in the Middle East beyond being a field of merely IranSaudi rivalry and a zone of proxy war. Likewise, a Shia block emerged with the support of Russia, Lebanon, Syria and Iraq for Iran ${ }^{50}$.

47 Saud Mousaed Al Tamamy, "Saudi Arabia and the Arab Spring:Opportunities and Challenges of Security", Journal of Arabian Studies, Vol. 2, Issue 2, 2012, pp.143-156, p. 143.

48 Florence Gaub, "Saudi Arabia and the Islamic Alliance", European Union Institute for Security Studies (EUISS), Brief Issue 1, 2016, p.4.

49 "Suudi Arabistan Yemen'de askeri operasyon başlattı", Ajans23, 26.03.1015, Erişim tarihi: 13.01.2016, http://www.ajans23.com/suudi-arabistan-yemende-askeri-operasyon-baslatti/8518/

50 Mehmet Seyfettin Erol, “Türk-Rus İlişkilerinde “Soğuk Savaş Sonrası Dönemde Rusya'nın Dış Politikasında Yekın Çevre ve Orta Asya", Türk Dünyası Incelemeleri Dergisi/Journal of Turkish World Studies, XIV/1 (Yaz 2014), p. 155-178, p. 165 
On the other hand, a kind of Sunni block was emerged with the support of Egypt, the UAE, Qatar, Bahrain, Kuwait, Jordan, Sudan and even Turkey for Saudi Arabia in the Yemen case. In addition, the US provided logistics and intelligence support and stood against Russia that supported Iran. In this framework, the Iran-Saudi rivalry in the Middle East was not between the two countries or regional, and it covers the global dimension of a great power struggle including the US and Russia. On the other hand, neither country outclassed the other in the proxy wars going on in Yemen nor thus a balance of proxy war took place. The apparent background of the Iran-Saudi rivalry in Yemen is the sectarian conflict between Sunni and Shia; however, the main axis of the conflict is the regional power struggle.

Syria is another area of the rivalry between Tehran and Riyadh. During the Arab Spring process, Syria has been pulled into a long ongoing civil war since 2011. The civil war in Syria turned to a proxy war between both regional powers and great powers. While the US and Russia conducts a proxy war in Syria as great powers, Iran and Saudi Arabia are the regional powers that conduct this proxy war ${ }^{51}$. The relations between Syria and Saudi Arabia started to deteriorate with the murder of Hariri, the Lebanon Prime Minister, in 2005 , however, the Saudi authority attempted to mend the relations to get Syria out of the Shia crescent. While Iran supports Assad who is among the Nusayri population which makes the $12 \%$ of the country and which are close to Shia, Saudi Arabia attempts to get Syria, that is $74 \%$ Sunni, out of the Iran axis and include it within its own zone of influence. However, the balance of power struggle between the two countries in Syria already turned to a balance of proxy war as in other regions.

\section{The Regional Dynamic of Rivalry: Arab Spring}

The regional dynamics of the Iran-Saudi rivalry consist of the Arab Spring phenomena that turned the Middle East geopolitics upside down. Arab Spring did not only collapsed the regimes of the Middle East states but also destructed the Middle East politics as well as the balance of power in the region. With the Arab Spring process, Libya, Yemen and Syria were dragged into a civil war and were no more regional actors. On the other hand, Turkey followed a policy of regional leadership in the Middle East from 2003 to the Arab Spring process in 2011, but was dragged into the Syria quagmire and unable to carry out a regional policy ${ }^{52}$. Egypt, another power of the region, entered into protection by Saudi Arabia after the el-Sisi coup. Likewise, Iraq is also under the control

51 Geraint Alun Hughes, "Syria and the perils of proxy warfare”, Small Wars E Insurgencies, 2014, Vol. 25, No. 3, 522-538, p.525.

52 Mehmet Seyfettin Erol, “Türkiye'nin Orta Asya politikasına Rusya Federasyonu ve Bölge ülkelerinden genel bir bakış", Türk Dünyası Incelemeleri Dergisi / Journal of Turkish World Studies, XII/1 (Yaz 2012), s. 1-20, s. 16

Akademik Bakış 147 Cilt 11 Sayl 21 KıŞ 2017 
of Iran, which leaves only Saudi Arabia, and Iran to conduct a leadership policy in the Middle East.

The fact that both countries took advantage of the Arab Spring as an opportunity for regional leadership pursuit and started their quest for a regional hegemony was the dynamic of this rivalry. Particularly, Iran started to carry out a policy to include the countries where Sunni regimes collapsed in the Arab Spring process into its own axis ${ }^{53}$. Beyond that, Iran framed the Arab Spring as a movement of Islamic awakening and followed a policy to make the Shia population in the Gulf countries to riot against Sunni governments ${ }^{54}$. Saudi Arabia recognized this intention of Iran in Bahrain and had to use military power to suppress the Shia riot in the country. Unlike Iran, Saudi Arabia considered the democratization demands during the Arab Spring process to be a threat against its own regime and the security of the Gulf countries ${ }^{55}$. Saudi Arabia had lost an ally like Egypt with Morsi from the Muslim Brothers coming to power with the Arab Spring process and with the rapprochement of Egypt with Iran, but it regained the support of Egypt by providing huge assistance after the el-Sisi coup.

Saudi Arabia acted to ensure the security of the Gulf countries in particular and tried to strengthen the Gulf Cooperation Council and to increase its military power ${ }^{56}$. On the other hand, the Gulf countries wanted closer relations and more military cooperation with Saudi Arabia against Iran threat that increased with the Arab Spring. This new cyclical situation created an opportunity for Saudi Arabia to establish a regional hegemony. Nevertheless, the Gulf countries had a trend to join in the hegemony of Saudi Arabia by themselves. Saudi Arabia used this fact to consolidate its already dominant position in the Gulf region.

\section{Global Dimension of Rivalry: The US' Changing Middle East Policy}

The US primarily started to establish a Middle East policy with the Truman doctrine in 1951 and determined its strategic interest in the context of the energy resources of the region, which are unchanged today. With the Eisenhower Doctrine in 1957, which includes military assistance as well as financial assistance, it started to follow an effective policy in the region. During this period, the US developed two special relationships in the Middle East with Saudi Arabia and Israel. Accordingly, the US and Saudi Arabia made commitments on military and security assistance and oil respectively ${ }^{57}$.

53 Henner Fürtig, Iran and the Arab Spring: Between Expectations and Disillusion, GIGA German Institute of Global and Area Studies, No. 241, Nov. 2013, p.9.

54 a.g.e., p.5

55 Guido Steinberg, Leading the Counter-Revolution Saudi Arabia and the Arab Spring, Stiftung Wissenschaft und Politik German Institute for International and Security Affairs, June 2014, Berlin, p.7.

56 Nawaf Obaid, Saudi Arabian Defense Doctrine, Belfer Center for Science and International Affairs, John F. Kennedy School of Government Harvard University, May 2014, p.13.

57 Tim Niblock, Saudi Arabia: Power, Legitimacy and Survival, Routledge, London and New York, 2006, p.41. 
In other words, the US-Saudi special relationship was established on the equation of security against oil. In 1960s, Nixon started to implement the "twin pillar" strategy to supervise the Gulf ${ }^{58}$. Thus the US started to control the region through its allies on both sides of the Gulf, i.e. Iran and Saudi Arabia. However, this policy collapsed with the 1979 Iran Islamic Revolution. Then the US implemented a dual containment policy for Iran and Iraq in 199359. After that, the US begun to execute its Middle East policy through Turkey, its NATO ally, and through Israel and Saudi Arabia which it had special relations with.

Following the September 11 terror attacks in 2001, the US changed its Middle East policy again and occupied Iraq in 2003 by implementing the preemptive strike strategy within the framework of the Bush doctrine. The US left its Middle East policy over its allies and started to implement its imperial project that was directly based on military presence in the region. However, this policy of the Bush administration failed as it caused the emergence of Iran as a regional power in addition to pushing Iraq to the zone influence area for $\operatorname{Iran}^{60}$. During the Obama administration, the foreign policy was reorganized for the shift of the US power to the Asia-Pacific against China, a superpower candidate. Accordingly, the Obama administration pulled its military presence in the region by shifting to the policy of leading from behind ${ }^{61}$. It could also be argued that it adopted the strategy of ruling the Middle East through its allies Israel and Saudi Arabia. In other words, it was stipulated that the gap left by the US would be filled by Saudi Arabia and Israel.

However, it was soon apparent in a short period of 6 years which was from 2011 to 2016 that Saudi Arabia was not able to establish a regional hegemony in the Middle East despite the support of the Gulf countries as well as the support of the US. Saudi Arabia was neither able to outclass Iran nor fill the gap left by the US. Yet Saudi Arabia was never a military power with a capacity to establish a regional hegemony despite its immense financial and oil power. On the other hand, historically no regional power alone was able to establish a regional hegemony in the Middle East ${ }^{62}$. There was always a multipolar balance of power system throughout the history that dominated the Middle East politics ${ }^{63}$. It was evident that Saudi Arabia did not have the capacity to become regional power or regional leader on its own.

58 Fürtig, Henner, "Conflict and Cooperation in the Persian Gulf: The Interregional Order and US Policy", The Middle East Journal, Volume 61, Number 4, Autumn 2007, pp. 627-640(14), p. 630.

59 Alex Edwards, Dual Containment" Policy in the Persian Gulf: The USA, Iran, and Iraq, 19912000, Palgrave Macmillan, New York, 2014, p. 53.

60 Athına Tzemprın, Jugoslav Jozıć, Henry Lambaré, “The Middle East Cold War: Iran-Saudi Arabia and the Way Ahead", Croatian Political Science Review, Vol.52 No.4-5 March 2016, p.192.

61 Sanford Lakoff, "Leading from Behind: The "Obama Doctrine" and US Policy in the Middle East”, Strategic Assessment, Vol. 16, No.1, April 2013, pp. 7-19, p.15.

62 Only exception is the relative hegemony of Egypt in the Middle East between 1950s and 1960s.

63 Lenore G. Martin, "Turkey and the USA in a Bipolarizing Middle East, Journal of Balkan and Near Eastern Studies, Volume 15, Issue 2: Turkish-US Relations, 2013, p.176.

Akademik Bakış 149 Cilt 11 


\section{Turkey as Balancing Power: Potential Turkish-Saudi Alliance}

The rapprochement started with the statement of Turkey to support Saudi Arabia in its Yemen operation and brought the idea of potential alliance between the two countries ${ }^{64}$. It could be argued that a dual regional dominant power and leadership would be conceivable with the partnership and alliance between Saudi Arabia with financial and oil power and Turkey with population more than Iran and with military power. I argued that Iran would be outcompeted in the Iran-Saudi rivalry with the support of Turkey to Saudi Arabia. However, the alliance of Turkey and Saudi Arabia against Iran includes the risk of sharpening the Shia crescent block leaded by Iran and the Sunni block leaded by Saudi Arabia ${ }^{65}$. In addition, Turk-Saudi alliance may not last long due to the leadership claims of both countries ${ }^{66}$. The leadership of alliance is another issue to be noted. Therefore, it could be anticipated that this alliance would be for a short term ${ }^{67}$. On the other hand, this polarization in the Middle East contains the risk of pushing the region to a more conflict-based atmosphere.

In return, it is understood that it would be more reasonable for Turkey to play the role of balancing power in the rivalry between the two countries. Yet the attempts of both Turkey and Saudi Arabia for their regional hegemonic policy failed and both countries experienced the fact that they did not have the capacity to become a regional hegemony on their own. A balancing policy to be followed by Turkey between the two countries would ensure a balance in the rivalry between the two countries as well as diminishing the instability in the region. Thus, the balance of power system in the Middle East may evolve to a multipolar structure like before and the confrontational rivalry in the region may enter into a détente period.

\section{Conclusion}

The Middle East geopolitics and the regional balance of power were broken with the occupation of Iraq by the US in 2003. The Arab Spring process not only broke the geopolitics, realpolitik and balance of power of the Middle East but also turned the region upside down with regard to socio-cultural, political and financial aspects. Therefore, a redesigning process started in the Middle East.

64 Gökhan Bacık, "The Iranian Moment and Turkey", The German Marshall Fund of the United States, No.125, 2016, pp.1-4, p.3. Erişim tarihi: 01.01.2017, file:///Users/Dr/Downloads/Bacik_IranianMoment_May16.pdf

65 Gallia Lindenstrauss and Yoel Guzansky, "Trying to Square the Circle: Can Saudi Arabia Form a United Sunni Front?", INSS Insight, No. 679, March 31, 2015, pp. 1-4, p.3.

66 Evangelos Venetis, The Struggle between Turkey E Saudi Arabia for the Leadership of Sunni Islam, The Hellenic Foundation for European and Foreign Policy (ELIAMEP), Athens, Greece, 2014, p. 4.

67 Jarryd de Haan, “Turkey-Saudi Relations in the Middle East", Independent Strategic analysis of Australia's Global Interests, Future Directions International, 16 June 2015, pp. 1-6, p.3, Erişim tarihi: 26.12.2016, http://futuredirections.org.au/wpcontent/uploads/2015/06/TurkeySaudi_Relations_in_the_Modern_Middle_East.pdf 
Maps were redrawn in the region and they tended to enhance their positions. In this context, the dynamics of rivalry between Iran and Saudi Arabia included the followings: 1. Sectarian differences-leadership of the Muslim world, 2. Geopolitical change, 3. Security dilemma, 4. Balance of power, 5. Regional hegemony. Iran and Saudi Arabia were alone together following that Iraq was no more in the Middle Eastern balance of power system after 2003, that Libya, Syria, Egypt and even Turkey has lost their regional actor positions since 2011 with the Arab Spring process. Both countries took advantage of this condition to become a regional hegemony.

Particularly Saudi Arabia with the new King Salman left its traditional status quo policy and entered into a regional hegemony quest by starting to follow an aggressive and ambitious foreign policy. Thus, Saudi Arabia added military power to its foreign policy along its financial power and started to play the role of leadership of the Muslim world and the Middle East region. However, Saudi Arabia recognized its limits in the Yemen operation and found out that its military power is not yet sufficient to become a regional hegemony. On the other hand, the rivalry between the two countries spread not only to the proxy war area where military tools are used but also to the energy field. Saudi Arabia started to have difficulties to maintain its cheap oil policy in its rivalry with Iran and even had to resort to its foreign exchange reserves. Meanwhile, the US-Saudi alliance started to weaken in the last periods of the Obama administration and Iran reached a settlement in nuclear negotiations with P5+1 along with the US-Iran rapprochement that were all critical elements that weakened the hand of Saudi Arabia in its rivalry with Iran. The fact that the US shifted its power to Asia Pacific and left the Middle East to its regional allies Israel and Saudi Arabia was the driving force behind the regional leadership policy option by Saudi Arabia. However, it could be argued that the new dimension of the US-Saudi special relationship that will emerge during the Trump period will have a decisive role in the regional position of Saudi Arabia.

Furthermore, the rivalry between the two countries appears to have accelerated the polarization process of the Middle East into Sunni and Shia blocks. Particularly the rapprochement tendency of Turkey with Saudi Arabia brought the Turkey-Saudi alliance to the agenda. However, it is anticipated that the Turkey-Saudi alliance will be for a short term due to the conflicting interests including the leadership problem and the regional hegemony quests of both countries. Instead, it is argued that Turkey may play a balancing role in the rivalry between the two countries, which most probably will moderate competition and prevent blocking. In the final analysis, the result of the Iran-Saudi rivalry will shape the geopolitics of the region by determining the balance of power and regional leadership in the Middle East, particularly in the Gulf region.

Akademik Bakış 151 Cilt 11 Sayı 21 Kış 2017 


\section{References}

AL TAMAMY Saud Mousaed, "Saudi Arabia and the Arab Spring:Opportunities and Challenges of Security", Journal of Arabian Studies, Vol. 2, Issue 2, 2012, pp.143-156.

AL-RASHEED Madawi, "Sectarianism as Counter-Revolution: Saudi Responses to the Arab Spring", Stud Ethn Nation, 11: 513-526.

AL-RASHEED Madawi, "Saudi Arabia and the quest for regional hegemony", Hurstpublishers, 19 July 2016, Erişim tarihi: 18.12.2016, http://www. hurstpublishers.com/saudi-arabia-quest-regional-hegemony/

AL-SHBOUL Hani Ahmed and Mohammad Salim Al-Rawashdeh, "Iran's Foreign Policy and the Balance of Power in the Region", Journal of Politics and Law, Vol. 6, No. 4; 2013, p. 200-209.

BACIK Gökhan, "The Iranian Moment and Turkey", The German Marshall Fund of the United States, No.125, 2016, pp.1-4, p.3. Erişim tarihi: 01.01.2017, file:///Users/ Dr/Downloads/Bacik_IranianMoment_May 16.pdf

BARZEGAR Kayhan, "Iran and the Shiite Crescent: Myths and Realities, Journal of World Affairs, Fall/Winter 2008, Vol. XV, Issue 1, pp. 87-99.

BERTI Benedetta and Yoel Guzansky, "Saudi Arabia's Foreign Policy on Iran and the Proxy War in Syria: Toward a New Chapter?", Israel Journal of Foreign Affairs, VIII:3, 2014, pp. 25-34.

BLACK Ian, "Fear of a Shia full moon", The Guardian, January 26, 2007, Erişim tarihi: 25.09.2016; https://www.theguardian.com/world/2007/jan/26/ worlddispatch.ianblack

BUZAN Barry and Ole Waever, Regions and Powers: The Structure of International Security, Cambridge University Press, Cambridge, New York, 2003.

COLE Juan, Kenneth Katzman, Karim Sadjadpour, Ray Takeyh, "A Shia Crescent: What Fallout for the United States?", Middle East Policy, Vol. 12, Issue 4, 2005, pp. 1-27.

DURAN Burhanettin and Nuh Yilmaz, "Islam, Models and the Middle East: The New Balance of Power following the Arab Spring", Perceptions, Winter 2013, Volume XVIII, Number 4, pp. 139-170.

EDWARDS Alex, Dual Containment" Policy in the Persian Gulf: The USA, Iran, and Iraq, 1991-2000, Palgrave Macmillan, New York, 2014.

EFEGİL Ertan, “Suudi Arabistan'ın Dış Politikasını Şekillendiren Faktörler”, Ortadoğu Analiz, Cilt 5, Sayı 53, Mayıs 2013, pp. 104-113.

EROL Mehmet Seyfettin, Çiğdem Tunç, “11 Eylül Sonrası ABD’nin Küresel Güç Mücadelesinde Orta Asya”, Avrasya Dosyası, Cilt: 9, Sayı: 3, Sonbahar 2003, pp. 5-28. 
EROL Mehmet Seyfettin, “Türkiye'nin Orta Asya politikasına Rusya Federasyonu ve Bölge ülkelerinden genel bir bakış", Türk Dünyası Incelemeleri Dergisi / Journal of Turkish World Studies, XII/1 (Yaz 2012), s.1-20.

EROL Mehmet Seyfettin, “Türk-Rus İlişkilerinde “Soğuk Savaş Sonrası Dönemde Rusya'nın Dış Politikasında Yekın Çevre ve Orta Asya”, Türk Dünyası İncelemeleri Dergisi/Journal of Turkish World Studies, XIV/1 (Yaz 2014), p. 155-178.

FÜRTIG Henner, "Conflict and Cooperation in the Persian Gulf: The Interregional Order and US Policy", The Middle East Journal, Volume 61, Number 4, Autumn 2007, pp. 627-640(14).

FÜRTIG Henner, Iran and the Arab Spring: Between Expectations and Disillusion, GIGA German Institute of Global and Area Studies, No. 241, Nov. 2013.

GAUB Florence, "Saudi Arabia and the Islamic Alliance", European Union Institute for Security Studies (EUISS), Brief Issue 1, 2016.

GAUSE III F. Gregory, Saudi Arabia in the New Middle East, Council on Foreign Relations, Council Special Report No.63, New York, 2011.

GILPIN Robert, War and Change in World Politics, Cambridge University Press, Cambridge, 1984.

HAAN Jarryd de, "Turkey-Saudi Relations in the Middle East", Independent Strategic analysis of Australia's Global Interests, Future Directions International, 16 June 2015, pp. 1-6, p.3, Erişim tarihi: 26.12.2016, http:// futuredirections.org.au/wpcontent/uploads/2015/06/TurkeySaudi_Relations_ in_the_Modern_Middle_East.pdf

HADDADIN Fadi A., "The 'Shia Crescent' and Middle East Geopolitics", Foreign Policy Association, January 31, 2017, Erişim tarihi: 02.02.2017, http:// foreignpolicyblogs.com/2017/01/31/shia-crescent-middle-east-geopolitics/

HERZ John, Political Realism and Political Idealism: A Study in Theories and Realities, University of Chicago Press, Chicago 1951.

HILTERMANN Joost, "A New Sectarian Threat in the Middle East", International Review of the Red Cross, Vol. 89, No. 868, December 2007, pp. 795-808.

h t t p://ns network. org/cms/as set s/uploads/2015/0 7 / StusterLimitsIransRegionalAmbitions.pdf

HUGHES Geraint Alun, "Syria and the perils of proxy warfare", Small Wars $\mathcal{E}$ Insurgencies, 2014, Vol. 25, No. 3, 522-538.

JAHNER Ariel, "Saudi Arabia and Iran: The Struggle for Power and Influence in the Gulf", International Affairs Review, Vol. XX, No.3, Spring 2012, pp. 37-50.

JAIN Sandhya, "Saudi Arabia: King Salman Faces the 21 st Century", Strategic Analysis, Vol. 39, Issue 3, 2015, pp. 280-286.

JOSCELYN Thomas, Iran's Proxy War Against America, The Claremont Institute, 2007. 
KARAGIANNIS Emmanuel, "The rise of Iran as a regional power: Shia empowerment and its limits", NATO Review Magazine, 2016, Erişim tarihi: 05.11.2016, http://www.nato.int/docu/Review/2016/Also-in-2016/iran-regionalpower-tehran-islamic/EN/index.htm

KATZMAN Kenneth, Iran's Foreign and Defense Policies, Congressional Research Service, Washington D.C. 2017.

LAKOFF Sanford, "Leading from Behind: The "Obama Doctrine" and US Policy in the Middle East", Strategic Assessment, Vol. 16, No.1, April 2013, pp. 7-19.

LINDENSTRAUSS Gallia and Yoel Guzansky, "Trying to Square the Circle: Can Saudi Arabia Form a United Sunni Front?", INSS Insight, No. 679, March 31, 2015, pp.1 4.

LUOMI Mari, Sectarian Identities or Geopolitics? The Regional Shia-Sunni Divide in the Middle East, The Finnish Institute of International Affairs, Helsinki, 2008.

MARTIN Lenore G., "Turkey and the USA in a Bipolarizing Middle East, Journal of Balkan and Near Eastern Studies, Volume 15, Issue 2: Turkish-US Relations, 2013.

MATTHIESEN Toby, " The domestic sources of Saudi foreign policy: Islamists and the state in the wake of the Arab Uprisings", Brookings Working Paper, Washington D.C. August 2015.

MEARSHEIMER John J., The Tragedy of Great Power Politics, W.W. Norton $\&$ Company, New York, London, 2001.

MERINGOLO Azzurra, "From Morsi to Al-Sisi: Foreign Policy at the Service of Domestic Policy", Insight Egypt, N.8, March 2015, pp.1-12.

MORGENTHAU Hans J., Politics Among Nations: The Struggle for Power and Peace, A. A. Knopf, 1948.

MUMFORD Andrew, Proxy Warfare, Polity Press, Cambridge, 2013.

MUMFORD, Andrew "Proxy Warfare and the Future of Conflict", The RUSI Journal, Vol. 158, Issue 2, 2013, pp.40-46.

NAZER Fahad, "ABD’yle Suudi Arabistan'ın “özel ilişkisi” sürecek mi?”, Al-

Monitor, Gulf Pulse, Nisan 8, 2016, Erişim tarihi: 04.12.2016, http://www.almonitor.com/pulse/tr/originals/2016/04/us-saudi-relations.html\#

NIBLOCK Tim, Saudi Arabia: Power, Legitimacy and Survival, Routledge, London and New York, 2006.

NURUZZAMAN Mohammed, "Saudi Airstrikes on Yemen: Limits to Military Adventurism", E-International Relations, May 20, 2015, Erişim tarihi: 26.12.2016, http://www.e-ir.info/2015/05/20/saudi-airstrikes-on-yemen-limits-to-militaryadventurism/

OBAID Nawaf, Saudi Arabian Defense Doctrine, Belfer Center for Science and International Affairs, John F. Kennedy School of Government Harvard University, May 2014. 
OSMAN Tarek, “Iran's Play for Middle Eastern Leadership", Foreign Affairs, January 20, 2017, Erişim tarihi: 28.01.2017,https://www.foreignaffairs.com/ articles/middle-east/2017-01-20/iran-s-play-middle-eastern-leadership

PAUL T.V., James J. Wirtz and Michel Fortmann (ed.), Balance of Power: Theory and Practice in the 21st Century, Stanford University, Stanford, California, 2004.

PISHEH Heshmatollah Falahat, "Shi'ite geopolitics and Iran's foreign policy", International Journal of Economy, Management and Social Sciences, Vol(3), No (5), May, 2014. pp. 278-281.

RAMAZANI R. K., Independence without Freedom: Iran's Foreign Policy, University of Virginia Press, Virginia, 2013.

REDA Latife, "Origins of the Islamic Republic's Strategic Approaches to Power and Regional Politics: The Palestinian-Israeli Conflict in Khomeini's Discourse", Middle East Critique, 25:2, 181-203, 2016.

REESE Aaron, Sectarian and Regional Conflict in the Middle East, The Institute for the Study of War, July 2013.

RICOTTA Jill, “ The Arab Shi'a Nexus: Understanding Iran's Influence in the Arab World", The Washington Quarterly, 39:2 pp. 139-154.

SHEEHAN, Michael The Balance of Power: History \& Theory, Routledge, London and New York, 1996.

STEINBERG Guido, Leading the Counter-Revolution Saudi Arabia and the Arab Spring, Stiftung Wissenschaft und Politik German Institute for International and Security Affairs, Berlin, 2014.

STUSTER J. Dana, “The Limits of Iran's Regional Ambitions”, National Security Network, Policy Brief, July 9, 2015, p. 1-9, p.6, Erişim tarihi: 14.08.2016, http:// nsnetwork.org/policy-brief-the-limits-of-irans-regional-ambitions/

"Saudi Arabia announces oil assistance, investments for Egypt", Ahram Online, Wednesday 16 December 2015, Erişim tarihi: 22.12.2016, http://english.ahram. org.eg/NewsContent/1/64/173627/Egypt/Politics-/Saudi-Arabia-announces-oilassistance,-investments.aspx

"Suudi Arabistan Yemen'de askeri operasyon başlattı", Ajans23, 26.03.1015, Erişim tarihi: 13.01.2016, http://www.ajans23.com/suudi-arabistan-yemendeaskeri-operasyon-baslatti/8518/

TANG Shiping, "The Security Dilemma: A Conceptual Analysis", Security Studies, 18:3, 587-623, 2009.

The Syrian Conflict: A systems Conflict Analysis, ARK Group, London, February 2016. TZEMPRIN Athına, Jugoslav Jozıć, Henry Lambaré, "The Middle East Cold War: Iran-Saudi Arabia and the Way Ahead", Croatian Political Science Review, Vol.52 No.4-5 March 2016. 
VENETIS Evangelos, The Struggle between Turkey \& Saudi Arabia for the Leadership of Sunni Islam, The Hellenic Foundation for European and Foreign Policy (ELIAMEP), Athens, Greece, 2014.

WEHREY Frederic, Theodore W. Karasik et. al, Saudi-Iranian Relations Since the Fall of Saddam Rivalry, Cooperation, and Implications for U.S. Policy, Rand Corporation, Santa Monica, USA, 2009.

YOUNG Karen E., "The Limits of Gulf Arab Aid: Energy Markets and Foreign Policy", European Centre for Energy and Resource Security, Vol. 1 07, Summer 2015, pp. 43-53. 